This document was prepared in conjunction with work accomplished under Contract No. DE-AC09-96SR18500 with the U.S. Department of Energy.

This work was prepared under an agreement with and funded by the U.S. Government. Neither the U. S. Government or its employees, nor any of its contractors, subcontractors or their employees, makes any express or implied: 1 . warranty or assumes any legal liability for the accuracy, completeness, or for the use or results of such use of any information, product, or process disclosed; or 2 . representation that such use or results of such use would not infringe privately owned rights; or 3 . endorsement or recommendation of any specifically identified commercial product, process, or service. Any views and opinions of authors expressed in this work do not necessarily state or reflect those of the United States Government, or its contractors, or subcontractors. 
PVP2007-CREEP8-26049

\title{
THERMAL TESTING OF 9977 GENERAL PURPOSE FISSILE PACKAGE USING A POOL FIRE
}

\author{
Lawrence F. Gelder \\ Savannah River National Laboratory \\ Westinghouse Savannah River Company \\ Aiken, South Carolina 29808 \\ (803) 725 8703, lawrence.gelder@srnl.doe.gov \\ Cecil G. May \\ Savannah River National Laboratory \\ Westinghouse Savannah River Company \\ Aiken, South Carolina 29808 \\ (803) 725 5813, cecil.may@srnl.doe.gov
}

\author{
John Malloy \\ NovaTech \\ Lynchburg, Virginia 24501 \\ (434) 239 1917, jmalloy@novatechusa.com
}

\author{
Glenn A. Abramczyk \\ Savannah River National Laboratory \\ Westinghouse Savannah River Company \\ Aiken, South Carolina 29808 \\ (803) 725 2996, glenn.abramczyk@srnl.doe.gov
}

\author{
Allen C. Smith \\ Savannah River National Laboratory \\ Westinghouse Savannah River Company \\ Aiken, South Carolina 29808 \\ (803) 725 2943, allen.smith@srnl.doe.gov
}

\begin{abstract}
The 9977 / 9978 General Purpose Fissile Package (GPFP), has been designed as a cost-effective, user-friendly replacement for the DOT 6M Specification Package for transporting Plutonium and Uranium metals and oxides. To ensure the capability of the 9977 GPFP to withstand the regulatory crush test, urethane foam was chosen for the impact absorbing overpack. As part of the package development it was necessary to confirm that the urethane foam overpack would provide the required protection for the containment vessel during the thermal test portion of the Hypothetical Accident Conditions Sequential Tests. Development tests of early prototypes were performed, using a furnace. Based on the results of the development tests, detailed design enhancements were incorporated into the final design. Examples of the definitive 9977 design configuration were subjected to an all-engulfing pool fire test, as part of the HAC Sequential Tests, to support the application for certification. Testing has confirmed the package's ability to withstand the HAC thermal tests.
\end{abstract}

\section{INTRODUCTION}

The 9977 / 9978 GPFP has been designed as a replacement for DOT 6M Specification Packaging. As such, it must be able to transport the Plutonium and Uranium metals and oxides, meet the Type B performance requirements, and be economical to build and use. In order to enable the GPFP to withstand the Hypothetical Accident Condition (HAC) Crush Test, urethane foam was chosen for the impact absorbing overpack material. Finite element modeling (FEM) indicated that the rigid urethane foam-filled overpack employed by the GPFP design would be able to withstand the Crush Test.

The ability of the urethane foam overpack to withstand the HAC Thermal Test requirement was less amenable to computer modeling and simulation than the structural tests, because of the complexity of modeling the thermal degradation process for the foam. Accordingly, thermal tests were performed for the development prototypes and the certification test packages. Based on the results of the development tests, detailed design enhancements were incorporated into the final design. Examples of the definitive configuration, of the GPFP, were 
subjected to the HAC Sequential Tests to support the application for certification.

\section{GPFP DESIGN}

The GPFP is conceptually similar to other drum packages, with a robust containment vessel contained within an overpack that provides protection against impact and fire. The GPFP employs the Chalfant containment vessel design, which is space efficient and very robust. The overpack incorporates a full liner, to facilitate decontamination. Impact protection and thermal insulation is provided by a thick, annular, urethanefoam layer. The outer shell is a stainless steel drum with a bolted, insulated closure.

Upper and lower load distribution fixtures center the containment vessel in the liner and protect the liner from sharp edges on containment vessel. They also stiffen the liner against radial loading during the horizontal Crush and help support the containment vessel during horizontal and shallow angle drops.

\section{DESIGN ENHANCEMENTS}

The results of testing of the prototype packages suggested several enhancements to the design. The tests showed that heat transfer along the liner and top plug shell resulted in substantial degradation of the foam insulation in the top plug and in the overpack at the top of the drum. To minimize this heat transfer, a layer of insulation above the lid flange was added and the top insulation in the top was changed from urethane foam to expanded vermiculite. In addition, the step in the liner was eliminated, so that the added top insulation overlapped the liner opening to the greatest possible extent. Accelerated degradation was observed in the prototypes along cracks induced in the foam during the structural tests. To provide additional margin against transfer of heat into the interior of the package along such cracks, a layer of Fiberfrax ${ }^{\circledR}$, inorganic insulation was added, surrounding the liner. Finally, decomposition products escaping through the bolt holes, for the top bolts, formed a tar-like residue on the interior of the liner and on the containment vessel. To avoid this, the bottoms of the threaded holes for the top bolts were closed.

The foam density for the definitive configuration was typically about $18 \mathrm{lb} / \mathrm{ft} 3$. The final configuration adopted the standard 18-1/2 in. diameter drum. This size is an industry standard and handling apparatus for it is readily available.

The 9977 configuration employs a 6 in. containment vessel, identical to the Secondary Containment Vessel of the 9975. For some applications, it is desirable to have a smaller containment vessel. To meet this need, the 9978 configuration employs a 5 in containment vessel, identical to the Primary Containment Vessel of the 9975.

\section{TEST PROGRAM}

\section{Test Packages}

The test packages were fabricated by Accurate Machine Products Co., The overpack foam installation operation was coordinated for SRS by the Kansas City Plant, and performed by General Plastics. Temperature indicating labels were installed on the exterior and interior of the containment vessels (CV), and at key locations in the interior of the overpack. The vessels were loaded with surrogate contents, a $100 \mathrm{lb}$ stainless steel cylinder, and leak tested before assembling them into the overpacks. The fully assembled packagings were then radiographed.

The practice burn was performed using a mock-up of a GPFP, without the urethane foam. The liner was attached to the upper deck-plate and insulated with the Fiberfrax layer, only.

\section{Facilities}

Prior to the thermal tests, the packages were subjected to the drop, crush and puncture test sequence. These tests were performed at SRS, using site drop testing facilities.

Thermal testing was performed at the South Carolina Fire Academy in Columbia, SC. An existing training prop, consisting of a concrete walled pool, $12 \mathrm{ft}$ square and $1 \mathrm{ft}$ high was employed for the tests. A wind fence, supported by a water-cooled frame and covered with a ceramic fiber insulation blanket, was erected around the pool wall. During the tests, the packages were supported one meter above the surface, on an insulated test stand with water cooled supports. An uncooled grating and vertical guides held the packages in position during the tests. The pool satisfies the requirement of extending a meter beyond the package on all sides. Water and fuel lines from central pumping stations maintained flow to the pool. A standpipe system insured constant water level in the pool during the tests. The fuel flow was distributed by a manifold under the surface of the water to insure uniform coverage of the pool, and regulated to maintain a fully engulfing fire. An array of eight thermocouples suspended in the enclosure, measured fire temperatures, directly. Four calorimeters, mounted on the package support stand, measured temperature by radiation. Thermocouples were mounted on the top of the package and on the un-cooled support grating beneath the package. The fire was ignited by a gas torch by a member of the fire academy staff and the test began when the fire became fully developed and fully engulfing. The test was terminated after the required thirty minute period, by securing fuel flow and allowing the fire to burn out.

Test Plan

The test plan subjected the prototype packages to the full HAC test sequence. The structural test orientations for the packages are shown in Tables 1 and 2. The crush tests were performed so that the crush plate struck the region damaged in 
the drop tests. The thermal test orientations corresponded to the structural test orientations.

Table 1 GPFP Certification Package Drop and Crush Test Orientations

\begin{tabular}{|l|l|l|l|l|}
\hline $\begin{array}{l}\text { Packaging } \\
\text { Identificati } \\
\text { on }\end{array}$ & $\begin{array}{l}\text { Drum } \\
\text { Diamet } \\
\text { er (in.) }\end{array}$ & $\begin{array}{l}\text { Foam } \\
\text { Density } \\
\text { (lb/ft3) }\end{array}$ & $\begin{array}{l}\text { Drop } \\
\text { Orientation }\end{array}$ & $\begin{array}{l}\text { Crush } \\
\text { Orientation }\end{array}$ \\
\hline $\begin{array}{l}\text { Practice } \\
\text { Pkg }\end{array}$ & $181 / 2$ & $\begin{array}{l}\text { No } \\
\text { foam }\end{array}$ & $\begin{array}{l}\text { Not subjected to structural } \\
\text { tests }\end{array}$ \\
\hline TP-2 & $181 / 2$ & 16 & $\begin{array}{l}\text { CGOC Top } \\
\text { Down }\end{array}$ & $\begin{array}{l}\text { CGOC Top } \\
\text { Down }\end{array}$ \\
\hline TP-3 & $181 / 2$ & 16 & Horizontal & Horizontal \\
\hline TP-4 & $181 / 2$ & 16 & $\begin{array}{l}\text { Axial Top } \\
\text { Down }\end{array}$ & $\begin{array}{l}\text { Axial } \\
\text { Bottom } \\
\text { Down }\end{array}$ \\
\hline TP-5 & $181 / 2$ & 16 & $\begin{array}{l}\text { Axial } \\
\text { Bottom } \\
\text { Down }\end{array}$ & $\begin{array}{l}\text { CGOC } \\
\text { Bottom } \\
\text { Down }\end{array}$ \\
\hline
\end{tabular}

Table 2. 9977 Certification Package Thermal Test Orientation

\begin{tabular}{|l|l|}
\hline Package Identification & Thermal Test Orientation \\
\hline Practice Package & Horizontal \\
\hline TP-2 & Top Down \\
\hline TP-3 & Horizontal \\
\hline TP-4 & Bottom Down \\
\hline TP-5 & Bottom Down \\
\hline
\end{tabular}

To account for the effect of heat generating contents, the certification test packages were preconditioned in an environmental chamber for at least four days at 93C. Approximately 20 hours before the fire test, the package was removed from the chamber, wrapped in insulation, transported to the test site. At the site, it was unwrapped, placed on the test stand fitted with band heaters and covered with an insulated enclosure until time for the start of the test. The insulated enclosure, supplementary insulation and heaters were removed one hour before the start of the tests. The preconditioning procedure was evaluated by thermal analysis to confirm that the interior temperatures would be representative of those in a package with maximum heat generating contents.

\section{Pool Fire Tests}

The certification test packages were subjected to the regulatory fully engulfing fire test, conducted in accordance with ASTM Standard E 2230-02. The tests were performed for SRNL by Novatech,, who have performed a number of previous fire tests for certification of radioactive material packages. A practice burn was performed using a mock-up of a GPFP without the urethane foam, to shakedown the equipment and procedures. The certification test packages were tested in the orientation expected to be most challenging.

The fire produces an orange-red flame with a large amount of soot. The visible flame extends about $45 \mathrm{ft}$, or more, above the wind fence. The fuel flow was controlled so that the flame "filled" the wind fence. That is, the fire extended to all four corners of the wind fence enclosure. The cooling water for the wind fence discharged onto the concrete pad surrounding the prop. The radiant heat from the flame resulted in rapid evaporation of this surface water. Following securing of the fuel flow, about two minutes were required for the fire to drop to the bottom of the package. At this point, the flame does not fill the wind fence area and the fire rapidly burns down. The last of the surface flame extinguished at around 2 mins. Typically, about 471 gal were consumed in the test.

The fire produces significant local drafts, which in turn affect the flame direction (i.e., which side of the fence it "leans" toward at any given moment).

Following the completion of each test, Digital Radiographic (DR) imaging of the test packaging was performed to evaluate the effects of the test on the internal structure of the packaging.

\section{RESULTS AND DISCUSSION}

The temperatures for the practice and certification tests are summarized in Table 3. The instrumentation confirms that the fire environment met the requirements for the regulatory thermal test (10CFR71.73(c)(4).

Table 3. Thirty Minute Average Temperatures

\begin{tabular}{|l|l|l|l|l|l|}
\hline Test & Package & $\begin{array}{l}\text { Fire } \\
\text { (C) }\end{array}$ & $\begin{array}{l}\text { DFT } \\
(\mathrm{C})\end{array}$ & $\begin{array}{l}\text { Package } \\
(\mathrm{C})\end{array}$ & $\begin{array}{l}\text { Optical } \\
\text { Thermo } \\
\text { meter } \\
(\mathrm{C})\end{array}$ \\
\hline Practice & $\begin{array}{l}\text { Practice } \\
\text { Package }\end{array}$ & 1014 & $\begin{array}{l}797 \\
(978 \mathrm{a})\end{array}$ & $889 \mathrm{~b}$ & 1041 \\
\hline $\begin{array}{l}\text { Regulatory } \\
\text { Test 1 }\end{array}$ & SN-2 & 1023 & 1109 & $968 \mathrm{c}$ & 883 \\
\hline $\begin{array}{l}\text { Regulatory } \\
\text { Test 2 }\end{array}$ & SN-4 & 848 & 888 & $791 \mathrm{c}$ & 1009 \\
\hline $\begin{array}{l}\text { Regulatory } \\
\text { Test 3 }\end{array}$ & SN-5 & 866 & 892 & $995 \mathrm{e}$ & $1065 f$ \\
\hline $\begin{array}{l}\text { Regulatory } \\
\text { Test 4 }\end{array}$ & SN-3 & 800 & 897 & 963 & 1009 \\
\hline
\end{tabular}

a - Value corrected for ten minute offset from burn time due to thermocouple lag.

b - TC on top of package only, lower TC moved inside package. 
c - These thermocouples were not calibrated for this test.

$\mathrm{d}-35$ minute average used because of longer burn.

$\mathrm{e}-\mathrm{TC}$ at the bottom of package is not included because of

false readings.

f - Only optical thermometer readings with 0.9 emissivity

included in average.

The temperature at key locations of the containment vessels are summarized in Table 4 . The temperatures in the containment vessels are well within the service temperature for the elastomer O-rings, in all cases. In the practice burn, the Practice Package (the mock-up GPFP) attained a maximum temperature of $435^{\circ} \mathrm{F}$, which is well within the limited duration service temperature for the o-ring seals in the containment vessel.

Table 4. Containment Vessel Temperatures

\begin{tabular}{|l|l|l|l|l|}
\hline $\begin{array}{l}\text { Temperature } \\
\text { Label Location }\end{array}$ & \multicolumn{4}{|l|}{ Maximum Temperature Indicated by Label } \\
\hline & SN-2 & SN-3 & SN-4 & SN-5 \\
\hline $\begin{array}{l}\text { Bottom of } \\
\text { Drum Closure } \\
\text { Plug }\end{array}$ & 290 & 380 & 435 & 435 \\
\hline $\begin{array}{l}\text { Inside of Cone } \\
\text { Seal Plug }\end{array}$ & $<250$ & 270 & 270 & $\begin{array}{l}\text { (label } \\
\text { damaged) }\end{array}$ \\
\hline $\begin{array}{l}\text { Inside CV } \\
\text { (close to } \\
\text { closure) }\end{array}$ & $<250$ & 270 & 260 & $<250$ \\
\hline $\begin{array}{l}\text { Outside CV } \\
\text { (close to } \\
\text { Closure) }\end{array}$ & $<250$ & 270 & 260 & $<250$ \\
\hline $\begin{array}{l}\text { Outside CV } \\
\text { (mid height) }\end{array}$ & $<250$ & $<250$ & $<250$ & $<250$ \\
\hline $\begin{array}{l}\text { Inside CV } \\
\text { (bottom) }\end{array}$ & $<250$ & 260 & $<250$ & $<250$ \\
\hline $\begin{array}{l}\text { Inside drum } \\
\text { liner at mid } \\
\text { height }\end{array}$ & $<250$ & 270 & $<250$ & $<250$ \\
\hline
\end{tabular}

Note: Label damage in SN-5 was mechanical damage caused by the surrogate contents.

The thermal degradation of the urethane foam results in loss of weight by the packages during the fire test. The weight losses for the test packages averaged $50.2 \mathrm{lb}$, with the exception of SN-3. As noted above, $\mathrm{SN}-3$ experienced a split along the chime, as a result of the crush test. This resulted in a loss of $53.5 \mathrm{lb}$ in the course of the test. The weight losses are summarized in Table 5.
Table 5. Weight Loss and time to extinguish

\begin{tabular}{|l|l|l|l|l|}
\hline $\begin{array}{l}\text { Package } \\
\text { SN }\end{array}$ & $\begin{array}{l}\text { Pre Test } \\
\text { Weight } \\
(\mathrm{lb})\end{array}$ & $\begin{array}{l}\text { Post Test } \\
\text { Weight } \\
(\mathrm{lb})\end{array}$ & $\begin{array}{l}\text { Change } \\
(\%)\end{array}$ & $\begin{array}{l}\text { Time to } \\
\text { extinguish, } \\
\text { min }\end{array}$ \\
\hline SN-2 & 342.3 & 293.1 & 66 & \\
\hline SN-3 & 339.8 & 286.3 & 71 & \\
\hline SN-4 & 343.4 & 291.6 & 69 & \\
\hline SN-5 & 341.0 & 291.4 & 66 & \\
\hline
\end{tabular}

The urethane foam intumesces as it undergoes thermal degradation, producing a voluminous, very low density charfoam decomposition product. In preliminary furnace tests of urethane foam overpacks, the char-foam was found to flow out of the fill and vent holes in the package and accumulate in large clumps in the furnace, which was an oxygen starved environment. In the fire tests, material exiting the package was burned away immediately. Combustible gaseous decomposition products jetted from the vent holes in the packages during and immediately after the fire exposure. These jets burned with a bright flame, which could be detected occasionally in the midst of the fire. The expanding char-foam material pushing against the bottom of Test Package 3, opened the tear formed in the crush test (without increasing its length). This resulted in the increased loss in foam mass (ca. 20\%) compared to the other packages, which was noted above. This behavior had been seen previously in the development package furnace tests. Because of the restricted venting of some of the packages, their bottoms were bulged by the intumescing of the degrading urethane foam.

Following the thermal exposure, all packages self extinguished.

The tests confirmed the ability of the urethane foam and Fiberfrax insulation system to protect the containment vessels from the fire.

\section{POST TEST EXAMINATION}

Following each test in the sequence, the packages were digitally radiographed to document the cumulative effects of the tests on the packages. Following completion of all the tests and final radiographs, the packages were cut open and the interior components examined. As part of this process, the containment vessels were removed for leak testing. For Test Package 3 it was possible to remove the containment vessel by opening the lid in the normal manner. In the other 3 cases, the containment vessel removed by cutting the bottom off of the liner. In all cases the fire test resulted in degradation of much of the urethane foam, with a residual cocoon of un-degraded urethane foam remaining attached to the FiberFrax blanket. 
The residual, un-degraded foam in Test Package 3, the package subjected to horizontal drop and crush, was almost separated in two lobes, rather than completely enclosing the liner. This was the result of accelerated thermal degradation of the foam in the regions where crushing and breakage of the foam had occurred from the drop and crush tests.

The examination of the residual, un-degraded urethane foam revealed cracks that were clearly present before the fire test. The radiographs showed indications that coincided with these features, indicating the stage in testing at which the cracking occurred. The buckling of the liner in Test Package 3, the horizontal test case, was seen in the radiographs to have occurred as a result of the 9-m drop.

The structure of the char-foam was similar in all cases. The degraded material varied from plastic rich material immediately adjacent to the undegraded foam, to frangible, carbonaceous or coked material on the outer surface, against the drum wall. When the outer shell was removed, the outer surface of the char-foam was convoluted with nodules of charfoam separated by deep channels or fissures.

The temperature labels installed on the inside of the liner and on the containment vessels confirmed that the interior temperatures were well within the acceptable range, in all cases. The maximum temperature recorded on a containment vessel was $270 \mathrm{~F}$ on the vessel from Test Package SN-3. The peak containment vessel temperature on the practice package (which had no urethane foam insulation) was $435^{\circ} \mathrm{F}$. This indicates that the FiberFrax layer alone is sufficient to provide the required thermal protection. The peak internal temperatures were found on the bottom of the top plug, being on the order of 270 F. These results are summarized in Table 4.

\section{CONCLUSIONS}

The sequential performance tests of the GPFP package demonstrated that the package meets the regulatory performance requirements of 10 CFR 71 with ample margin.

Although Test Package 3 withstood the subsequent thermal tests, the tear which occurred at the package in the crush test is undesirable. Accordingly, a revised drum bottom design will be employed for the production packages.

The outer shell of urethane foam overpacks must allow sufficient venting in the fire event to prevent over pressurization of the overpack (i.e., pressurization that could result in failure of the outer shell of the package.

\section{DISCLAIMER}

This document was prepared in conjunction with work accomplished under Contract No. DE-AC09-96SR18500 with the U. S. Department of Energy. DISCLAIMER This report was prepared as an account of work sponsored by an agency of the United States Government. Neither the United States
Government nor any agency thereof, nor any of their employees, nor any of their contractors, subcontractors or their employees, makes any warranty, express or implied, or assumes any legal liability or responsibility for the accuracy, completeness, or any third party's use or the results of such use of any information, apparatus, product, or process disclosed, or represents that its use would not infringe privately owned rights. Reference herein to any specific commercial product, process, or service by trade name, trademark, manufacturer, or otherwise, does not necessarily constitute or imply its endorsement, recommendation, or favoring by the United States Government or any agency thereof or its contractors or subcontractors. The views and opinions of authors expressed herein do not necessarily state or reflect those of the United States Government or any agency thereof.

\section{REFERENCES}

1. ASTM Standard E 2230-02, "Standard Practice for Thermal Qualification of Type B Packages for Radioactive Material"

2. L. F. Gelder, A. C. Smith and P. S. Blanton, "General Purpose Fissile Packaging Prototype Tests”,. Savannah River National Laboratory Technical Report M-TRT-A-00006, November, 2004.

3. L. F. Gelder, C. M. May, "9977 General Purpose Fissile Packaging Prototype Testing”,. Savannah River National Laboratory Technical Report M-TRT-A-00007, May , 2006

Burgess, M. H., and Fry, C. J., "Fire Testing for Package Approval", International Journal of Radioactive Materials Transport, Vol. 1, No. 1, 1990.

Feldman, M. R., Thermal Testing of Type b Packages in Furnaces per ASTM Standard Practice E 2230”, Packaging, Transport, Storage and Security of Radioactive Material, Vol. 17, No. 3, 2006. 


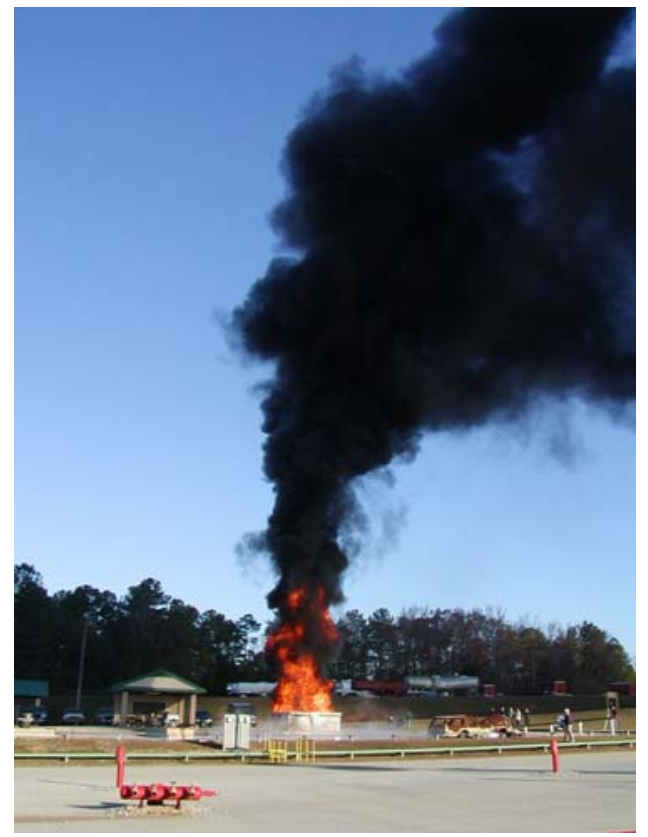

Figure 1. Fire Test of Package P-2.

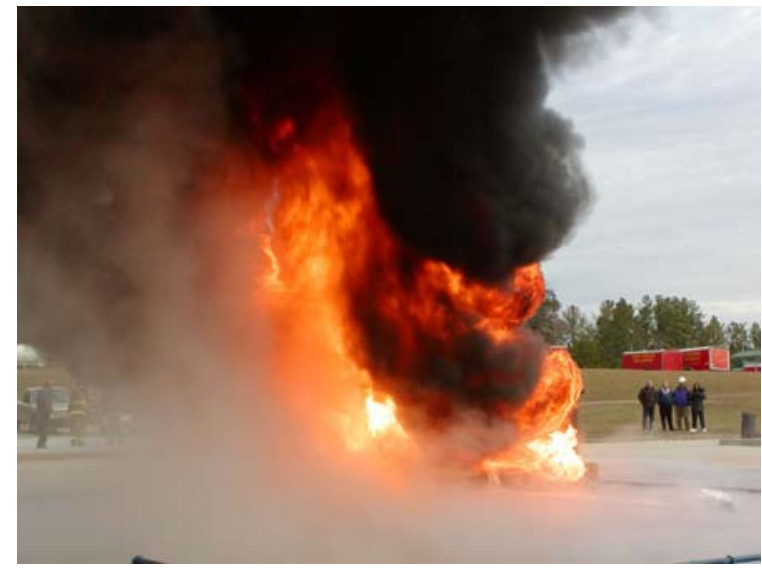

Figure 2. Fire Test of Package TP-3.

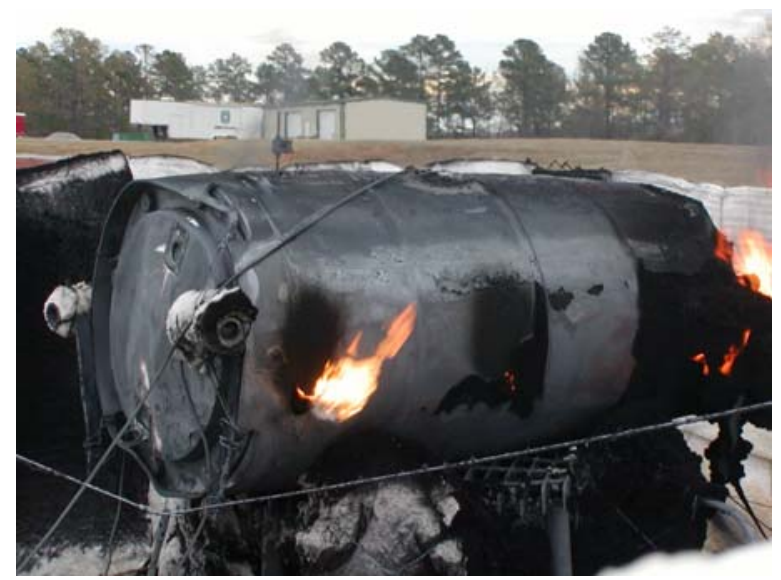

Figure 3. Package TP-3 cooling after fire.

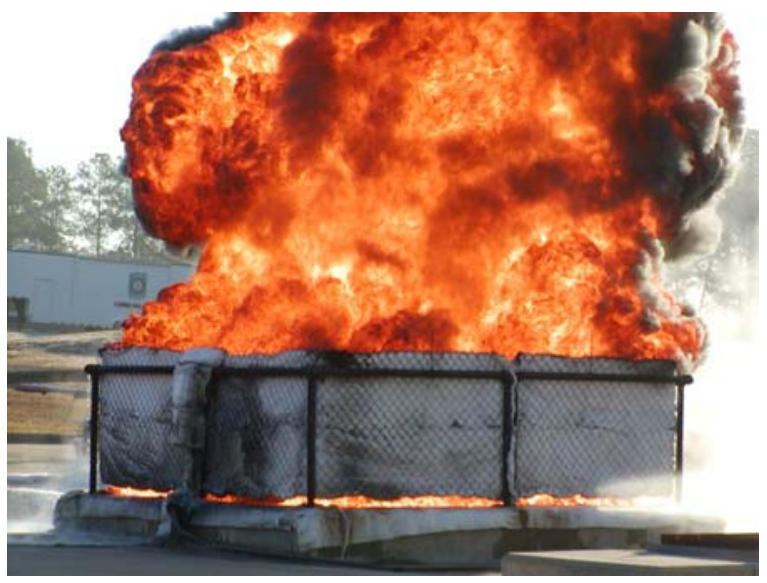

Figure 4. Fire Test of Package TP-5.

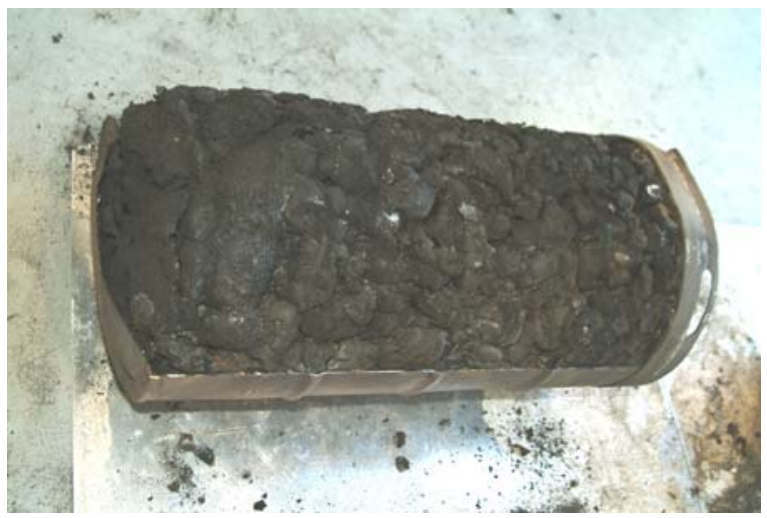

Figure 5. Under fire conditions, polyurethane foam intumesces and produces a low density charfoam decomposition product. The package shown is TP-3.

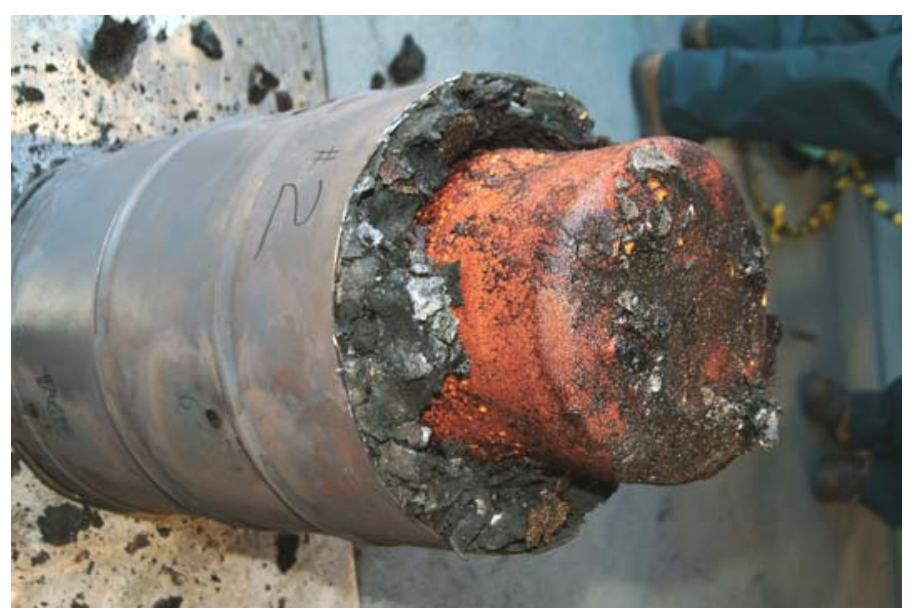

Figure 6. The undegraded foam remains as an unaffected layer surrounding the liner. The package shown is TP-2. 